\title{
DNA Isolation and Optimization of ISSR-PCR Reaction System in Oryza sativa L.
}

\author{
Azhar Mohamad ${ }^{\#}$, Arshad Naji Alhasnawi ${ }^{+}$, Ahsan A. Kadhimi ${ }^{*}$, Anizan Isahak ${ }^{\& 1}$, Wan Mohtar Wan \\ Yusoff $^{\& 2}$, Che Radziah C.M.Z \&3 \\ \# Malaysian Nuclear Agency, 43000 Kajang, Bangi, Malaysia \\ E-mail: azhar_m@nuclearmalaysia.gov.my \\ ${ }^{+}$Department of Biology, College of Education for Pure Sciences, Al Muthanna University, 66001 Samawah, Iraq \\ E-mail:arshad@mu.edu.iq \\ * University of Baghdad, Jadriyah, 10070 Baghdad, Iraq \\ E-mail: kkkihsan@yahoo.com
}

${ }^{\&}$ School of Biosciences \& Biotechnology, Universiti Kebangsaan Malaysia, 43600 UKM Bangim, Selangor, Malaysia E-mail: ${ }^{2}$ anizan@ukm.edu.my, ${ }^{2}$ wantarukm@gmail.com, ${ }^{3}$ cradziah@ukm.edu.my

\begin{abstract}
Inter simple sequence repeats (ISSRs) have been utilized widely for molecular markers in analyzing the genetic diversity and phylogenetic and regions in the genome flanked by microsatellite sequences. PCR amplification of these regions using a single primer yields multiple amplification products that can be used as a dominant multilocus marker system for the study of genetic variation in various organisms. For this study provides, DNA isolation, adjusting in six factors (Buffer, $\mathbf{M g C l}_{2}, \mathrm{dNTPs}_{\mathbf{2}}$ ISSR primers, Template DNA and Taq polymerase) at six levels, and optimization of PCR temperature for the ISSR reaction was 60-45 ${ }^{\circ} \mathrm{C}$, primers screening on indica rice (Oryza sativa). In this research, simple method of DNA isolation by using seedling. The objective of the present investigation was to assess the optimizations and quantification. Has been shown that stalk enhanced the maximum value of genomic. The results show that 100 ISSR primers were examined as well as, 56 ISSR primers was productively amplified. Optimum components for PCR reactions were $5.0 \mu \mathrm{l}$ of $5 X$ PCR Buffer, $1.5 \mu \mathrm{l}$ of $25 \mathrm{mM} \mathrm{MgCl}, 1 \mu \mathrm{l}$ of $10 \mathrm{mM} \mathrm{dNTP,} 1 \mu \mathrm{l}$ of $10 \mathrm{Mm}$ ISSR primers, $2 \mu \mathrm{l}$ Template DNA, and $0.1 \mu \mathrm{l}$ of $5 \mathrm{units} / \mathrm{ml}$ Taq polymerase. Based on this study, has brought out some information on the relationship between these ISSR primers will be applied further for molecular profiling as well as response evaluation in rice varieties.
\end{abstract}

Keywords - DNA isolation; optimal PCR condition; ISSR screening; plant genetics.

\section{INTRODUCTION}

Rice (Oryza sativa L.) is the record primary food crop in the global [1]. It role is an important cereal crop for world food security and is used to food more than 3 billion persons on an everyday calorie intake of between 50 to $80 \%$ [2]. However, the United Nations has been reported the request for rice increments for the populace which is probably to increase by a more $38 \%$ within 30 years, [3]. It's also nutrition, particularly for developing countries and Asian cultured rice is an essential as a staple food crop [4]. The cultivable area under rice needs to be increased to improve the production demands.

ISSR is a microsatellite-based multilocus marker method, which is useful and straightforward for genetic assessment diversity in various crop plants [5]. ISSR markers are highly polymorphic polymorphism of bands and are beneficial in researches on genetic diversity, genome mapping, evolutionary biology, phylogeny, and gene tagging [6]. Also notes Reddy et al., [7] investigated the ISSR-PCR detection, which affects, the utilize of microsatellite sequences as primers in PCR to produce multilocus markers. The markers from ISSR are useful and extremely polymorphic in evaluation on genome mapping, evolutionary biology, phylogeny, gene tagging and genetic diversity. Also ISSR, their capacity to detect variation without any prior sequence information. The technique and its application in plant breeding and genetics in a wide range of crop plants [7]. Blair et al. [8], investigated the distinguished rice genotypes (indica and japonica), applying ISSR polymorphism data. ISSR marker availability technology an effect on for the 
production of possible fingerprinting assessment marker for, cultivars, species, and genomes, moreover phylogenetic investigation on the basis of the ISSR technique, resulting phenogram holds polyphyletic development in the genus Oryza, wherein multiple heredities undergo independent deviation later than division from a general ancestor [9].

However, none of these studies have focused on optimize and selected of ISSR primers as a part of the venture on a biological indicator to increase the molecular tools available to obtain genetic information in rice. The principal objective of this research was to examine the extraction procedure for DNA rice and to assessment ISSR primer in indica rice based on optimization annealing temperatures. Our research includes DNA isolation, quantification, PCR optimization, primers selection, and detection for Malaysian local rice MRQ74 rice.

\section{MATERIALS AND METHODS}

The MRQ74 genotype of indica rice used in this research to optimum annealing temperature for ISSR primers was conducted in the Malaysian Nuclear Agency Laboratory during 2015.

\section{A. DNA Isolation}

For DNA extraction, leaf tissue was collected various pots of MRQ74 variety (Figure 1). The genomic DNA rice varieties were isolated using freshly collected young leaves. The white powder form of fresh seedling rice from green colored to a fine powder from mortar was got when ground in liquid nitrogen $\left(-196^{\circ} \mathrm{C}\right)$ was used for DNA extraction. To extract genomic DNA the CTAB technique was used with some modifications. One gram of freshly harvested young leaves was grounded into powder using a mortar and pestle in liquid nitrogen. The powder was then directly transferred into Eppendorf tube size $50 \mathrm{ml}$ containing $15 \mathrm{ml}$ preheated extraction buffer made up of $[1.4 \mathrm{M} \mathrm{NaCl}, 100 \mathrm{mM}$ TrisHCI, 20 mM EDTA (pH 8), 3\% CTAB, and 2\% PVP]. Then it was incubated in a water bath with the addition of $30 \mu \mathrm{L}$ Mercaptoethanol solution at $60^{\circ} \mathrm{C}$ for $1 \mathrm{~h}$ in water bath, the tube was gently shaken at $10 \mathrm{~min}$ intervals. Then one volume of chloroform/isoamyl alcohol (24/1) v/v mixture was added in the same tube after incubation and inverted. This followed a centrifugation at $5000 \mathrm{rpm}$ at $25^{\circ} \mathrm{C}$ for 10 minute. The supernatant was put in a new Eppendorf tubes (Volume $1.5 \mathrm{ml}$ ), its DNA was precipitated through and supplemented with cold isopropanol (0.6 volume) then placed in ice for $30 \mathrm{~min}$. DNA precipitate was fished out and placed into Eppendorf tube following a centrifugation at $12000 \mathrm{rpm}$ for $10 \mathrm{~min}$. The DNA pellet was collected and washed using $200 \mu \mathrm{L}$ of ethanol $(70 \%)$. The mixtures were pulsed spin by centrifuged at $12000 \mathrm{rpm}$ once and the ethanol discarded. However, to collected for the DNA pellet was air-dried and re-suspended in $300 \mu \mathrm{L}$ TE buffer then incubated at $4^{\circ} \mathrm{C}$ overnight and continued with DNA precipitation.

The DNA pellet obtained from the previous step was later supplemented with $3 \mathrm{M}$ sodium acetate (1/10 volume) and cold absolute ethanol ( 2 volume). Gently mix by inverting Eppendoft tube and incubate on ice for $30 \mathrm{~min}$ then centrifuged at $12000 \mathrm{rpm}$ for $10 \mathrm{~min}$ at $4^{\circ} \mathrm{C}$ for DNA precipitation and the supernatant was removed. The DNA pellet was rinsed using ethanol $100 \mu \mathrm{L}$ (70\%) then centrifuged at $12000 \mathrm{rpm}$ for $1 \mathrm{~min}$ at $4{ }^{\circ} \mathrm{C}$, the process was repeated two times. DNA was left to dry at room temperature and $100 \mu \mathrm{L}$ TE buffer was added to each tube. DNA was kept in $-20^{\circ} \mathrm{C}$ freezer overnight and then $1 \mu \mathrm{L}$ RNase was added, DNA was left to incubate for 1 hour at $37^{\circ} \mathrm{C}$. DNA was then ready to be utilized in agarose gel electrophoresis [10].

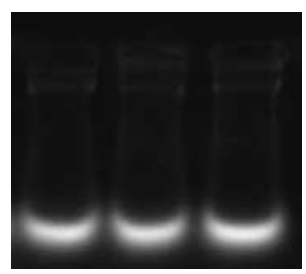

Fig. 1. Gel electrophoresis image of DNA quality extracted using CTAB method at $1.0 \%$ agarose, 70 volts, 20 minutes

\section{B. DNA Electrophoresis and Quantification}

The DNA concentrations were determined using Nanodrop Spectrophotometer model (Nanodrop 1000 brand Thermo Scientific). Loading $1 \mu \mathrm{l}$ of each DNA sample was put on Nanodrop was used for DNA quantification.

The purity of recovered total DNA (Table 1), was used measuring the absorbance ratio at (260-280) $\mathrm{nm}$ [11].

TABLE I

AMOUNT OF GENOMIC DNA EXTRACTED USING CTAB METHOD

\begin{tabular}{|c|c|c|}
\hline Sample & $\begin{array}{c}\text { Average DNA } \\
\text { concentration } \\
(\mathbf{n g} / \boldsymbol{\mu l})\end{array}$ & $\begin{array}{c}\text { Average } \\
\text { OD260/280 }\end{array}$ \\
\hline MRQ74 Rice seedlings & $70.20 \pm 2.6$ & $1.9 \pm 0.15$ \\
\hline
\end{tabular}

\section{PCR Master Mix Optimization}

Different volumes of PCR reagent parameter [IS32 (TG)8G (17 mer)] such as a buffer, Primer $\mathrm{MgCl}_{2}, \mathrm{Taq}$ polymerase, dNTP, and DNA template [12], were optimized as in (Table 2) by giving total volumes of $25 \mu$ for each reaction.

\section{Primers Selection and PCR Optimization}

A set of 100 ISSR primers were obtained from the Malaysian Nuclear Agency and screened for their repeatable amplification used in this study are presented in (Table 1). Fresh leaf tissue of MRQ74 variety samples was used.

DNA templates to generate a six temperature fragment utilized were in the range of 60 to $40^{\circ}$ to determination the best PCR amplification temperature. ISSR primer with highest amplifications result was selected for ISSR evaluates. Used master mix $(25 \mu l$ reaction) was placed in a thermo cycle machine, for PCR gradient analysis, (Bio Rad, T100 ${ }^{\mathrm{TM}}$ Thermal Cycler).

Consisted which of $14.4 \mu \mathrm{l}$ sigma water, $5 \mu \mathrm{l} 5 \mathrm{X}$ PCR buffer, $1.5 \mu \mathrm{l}$ of $10 \mathrm{Mm} \mathrm{MgCl}_{2}, 1 \mu \mathrm{l}$ of $10 \mathrm{mM}$ dNTPs mixed, $1 \mu \mathrm{l}$ of $0.4 \mu \mathrm{M}$ ISSR primers, $2 \mu \mathrm{l}$ of template DNA (50-100 ng/ $\mu \mathrm{l}$ ) (Table 2), and $0.1 \mu \mathrm{l}$ Taq DNA polymerase. PCR protocol was started thru hot start then follows thru specific thermal cycles as followed single step of initial [13]. 
- Thermocycler Set-up

Initial denaturation $94^{\circ} \mathrm{C}$ ( 2 mines); [Denaturation $94^{\circ} \mathrm{C}$ (1 min); Annealing $45-60^{\circ} \mathrm{C}(50 \mathrm{~s})$; Elongation $\left.72^{\circ} \mathrm{C}(50 \mathrm{~s})\right]$ for 31 cycles; Final extension at $72^{\circ} \mathrm{C}(5$ mines $)$; End $\left(10^{\circ} \mathrm{C}\right)$. PCR Cycles: Repeat from step (Denaturation to Elongation) for 31 cycles. The enhancement of amplified was separated using electrophoresis on agarose gel $(1.5 \%)$ in TAE (1X) for $60 \mathrm{~min}$ and the DNA fingerprints images were assessed using an automatic imaging system.

\section{- DNA Quantification and Gel Electrophoresis}

For the purpose of DNA quantification related to the DNA extraction, Nanodrop Spectrophotometer machine by use was used to calculate the concentration of DNA and the purity, the relative purity with the concentrations of the DNA extract was showed. The last DNA concentrations were diluted by using TE buffer. Right after PCR, desired products were then separated on $1.5 \%$ agarose gels run at the condition of 70 Volts and $400 \mathrm{~m}$ Amps for 50 minutes by using Thermo Scientific EC 300 XL Power Supply model (EC300XL2), USA. The visualized of DNA bands by using automatic imaging system under UV light (MS major science model UVCI-1100, USA) and photographed using Gel Documentation System, model UVCI-1100, Major Science. The size of the desired genes was estimated by using 100 bp DNA ladder. DNA bands images were select using an automatic imaging system.

\section{E. Polymerase Chain Reaction (PCR)}

1) Tore all PCR components on ice

2) Prepare a stripe PCR tube (8 tubes with lids)

3) Prepare Master Mix (MM) (Table 3)

\section{F. Primers Optimization ISSR (Rice)}

Annealing temperature: $1-60 \mathrm{C}^{\circ}, 2-58.8 \mathrm{C}^{\circ}, 3-56.9 \mathrm{C}^{\circ}$, 4- $54.2 \mathrm{C}^{\circ}, 5-50.7 \mathrm{C}^{\circ}, 6-47.8 \mathrm{C}^{\circ}$

\section{G. Agarose Gel Electrophoresis}

1) Dissolve 1.5g Agarose in 100ml $1 \mathrm{X}$ TAE (Tris Acetate EDTA) buffer (40 mM Tris, $1 \%(\mathrm{v} / \mathrm{v})$ acetic acid, 1 mM EDTA, pH 8.0)

2) Once dissolve. Wait to cool and add $1 \mu \mathrm{l}$ Ethidium Bromide Solutions, $10 \mathrm{mg} / \mathrm{ml}$.

3) Mix well and pour to cast (7 wells cast)

4) Add $5 \mu \mathrm{l} \mathrm{Gel} \mathrm{Loading} \mathrm{(6X)} \mathrm{mixed} \mathrm{well} \mathrm{to} \mathrm{each} \mathrm{of}$ digest samples

5) Run at $70 \mathrm{~V}$ for $1 \mathrm{~h}$ in TAE buffer

6) Observe under imaging system

TABLE II

OPTIMIZATION OF PCR BY USING DIFFERENT VOLUMES OF REAGENTS BY USING PRIMER IS 32 AT $54.2{ }^{\circ} \mathrm{C}$

\begin{tabular}{|c|c|c|c|c|c|c|c|c|c|c|c|c|c|}
\hline \multicolumn{2}{|l|}{ Reagent } & \multicolumn{5}{|c|}{ 5X PCR buffer } & \multicolumn{3}{|l|}{ Reagent } & \multicolumn{4}{|c|}{ Primer $(\mu \mathrm{l})$} \\
\hline$\Sigma \mathrm{H}_{2} \mathrm{O}$ & 18.4 & 15.9 & 13.4 & 10.9 & 8.4 & 5.9 & $\Sigma \mathrm{H}_{2} \mathrm{O}$ & 15.4 & 14.9 & 14.4 & 13.9 & 13.4 & 12.9 \\
\hline $\mathrm{MgCl}_{2}$ & 1.5 & 1.5 & 1.5 & 1.5 & 1.5 & 1.5 & $\mathrm{MgCl}_{2}$ & 1.5 & 1.5 & 1.5 & 1.5 & 1.5 & 1.5 \\
\hline PCR Buffer & 0 & 2.5 & 5 & 7.5 & 10 & 12.5 & PCR Buffer & 5 & 5 & 5 & 5 & 5 & 5 \\
\hline dNTP & 1 & 1 & 1 & 1 & 1 & 1 & dNTP & 1 & 1 & 1 & 1 & 1 & 1 \\
\hline Primer & 2 & 2 & 2 & 2 & 2 & 2 & Primer & 0 & 0.5 & 1 & 1.5 & 2 & 2.5 \\
\hline Template DNA & 2 & 2 & 2 & 2 & 2 & 2 & Template DNA & 2 & 2 & 2 & 2 & 2 & 2 \\
\hline Taq Polymerase & 0.1 & 0.1 & 0.1 & 0.1 & 0.1 & 0.1 & Taq Polymerase & 0.1 & 0.1 & 0.1 & 0.1 & 0.1 & 0.1 \\
\hline \multicolumn{2}{|l|}{ Reagent } & \multicolumn{5}{|c|}{$\mathrm{MgCl}_{2}(\mu \mathrm{l})$} & \multicolumn{2}{|l|}{ Reagent } & \multicolumn{4}{|c|}{ Taq polymerase $(\mu \mathrm{l})$} & \\
\hline$\Sigma \mathrm{H}_{2} \mathrm{O}$ & 14.9 & 13.9 & 13.4 & 12.9 & 12.4 & 11.9 & $\Sigma \mathrm{H}_{2} \mathrm{O}$ & 13.5 & 13.4 & 13.2 & 12.9 & 12.6 & 12.3 \\
\hline $\mathrm{MgCl}_{2}$ & 0 & 1 & 1.5 & 2 & 2.5 & 3 & $\mathrm{MgCl}_{2}$ & 1.5 & 1.5 & 1.5 & 1.5 & 1.5 & 1.5 \\
\hline PCR Buffer & 5 & 5 & 5 & 5 & 5 & 5 & PCR Buffer & 5 & 5 & 5 & 5 & 5 & 5 \\
\hline dNTP & 1 & 1 & 1 & 1 & 1 & 1 & dNTP & 1 & 1 & 1 & 1 & 1 & 1 \\
\hline Primer & 2 & 2 & 2 & 2 & 2 & 2 & Primer & 2 & 2 & 2 & 2 & 2 & 2 \\
\hline Template DNA & 2 & 2 & 2 & 2 & 2 & 2 & Template DNA & 2 & 2 & 2 & 2 & 2 & 2 \\
\hline Taq Polymerase & 0.1 & 0.1 & 0.1 & 0.1 & 0.1 & 0.1 & Taq Polymerase & 0 & 0.1 & 0.3 & 0.6 & 0.9 & 1.2 \\
\hline \multicolumn{2}{|l|}{ Reagent } & \multicolumn{4}{|c|}{ dNTP $(\mu \mathrm{l})$} & & \multicolumn{2}{|l|}{ Reagent } & \multicolumn{4}{|c|}{ DNA $(\mu \mathrm{l})$} & \\
\hline $\mathrm{\Sigma H}_{2} \mathrm{O}$ & 14.4 & 13.9 & 13.4 & 12.9 & 12.4 & 11.9 & $\Sigma \mathrm{H}_{2} \mathrm{O}$ & 15.4 & 14.4 & 13.4 & 12.4 & 11.4 & 10.4 \\
\hline $\mathrm{MgCl}_{2}$ & 1.5 & 1.5 & 1.5 & 1.5 & 1.5 & 1.5 & $\mathrm{MgCl}_{2}$ & 1.5 & 1.5 & 1.5 & 1.5 & 1.5 & 1.5 \\
\hline PCR Buffer & 5 & 5 & 5 & 5 & 5 & 5 & PCR Buffer & 5 & 5 & 5 & 5 & 5 & 5 \\
\hline$d N T P$ & 0 & 0.5 & 1 & 1.5 & 2 & 2.5 & $\mathrm{dNTP}$ & 1 & 1 & 1 & 1 & 1 & 1 \\
\hline Primer & 2 & 2 & 2 & 2 & 2 & 2 & Primer & 2 & 2 & 2 & 2 & 2 & 2 \\
\hline Template DNA & 2 & 2 & 2 & 2 & 2 & 2 & Template DNA & 0 & 1 & 2 & 3 & 4 & 5 \\
\hline Taq Polymerase & 0.1 & 0.1 & 0.1 & 0.1 & 0.1 & 0.1 & Taq Polymerase & 0.1 & 0.1 & 0.1 & 0.1 & 0.1 & 0.1 \\
\hline
\end{tabular}

\section{RESULT AND DISCUSSION}

For DNA purity, all samples had a robust absorbance ratio according to the range of the absorbance, and our results are in agreement with Ferdous et al. [14] the range of absorbance A260/A280 ratio 1.8-2 for DNA purity and quality was more than sufficient. In the present investigation, PCR reactions were chosen for better reproducibility, banding patterns and amplification.

To obtain PCR amplification, 5X PCR buffer, $25 \mathrm{mM}$ $\mathrm{MgCl}_{2}, 10 \mathrm{mM} \mathrm{dNTP}$, ISSR primer, Template DNA and 5 units/ml Taq polymerase are required in specific concentrations for selection of relatively polymorphic bands that are reproducible and produced clear bands. Buffers at $(0$, $2.5,5,7.5,10$, and $12.5 \mu \mathrm{l})$ buffer concentrations were optimum in these experimental. However, $5 \mu \mathrm{l}$ buffers showed clear amplification of PCR products bands (Figure 2; A).

The optimization of Taq polymerase using different concentrations includes $(0,0.1,0.3,0.6,0.9$ and $1.2 \mu \mathrm{l})$. The result of gel electrophoresis image showed all concentrations reproduced the amplification of PCR products but the clarity 
bands were observed with $0.1 \mu \mathrm{l}$ of Taq polymerase (Figure 2 ; B). The dNTP concentrations $(0,0.5,1,1.5,2$, and $2.5 \mu \mathrm{l})$, were optimum in this study, clear bands were observed in 1 $\mu \mathrm{l}$ of dNTP (Figure 2; C). The ISSR primer concentrations ( 0 , $0.5,1,1.5,2$, and $2.5 \mu \mathrm{l}$ ) were optimumal, in the present study the concentration $1 \mu \mathrm{l}$ of ISSR primer showed band clarity of PCR amplicons (Figure 2; D).

TABLE III

AOUNT OF PCR MASTER MIX

\begin{tabular}{|l|l|l|l|}
\hline \multicolumn{1}{|c|}{ Reagent } & \multicolumn{1}{c|}{$\begin{array}{c}\text { Final } \\
\text { Concentration }\end{array}$} & \multicolumn{1}{c|}{$\begin{array}{c}\text { Volume } \\
(\boldsymbol{\mu l})\end{array}$} & $\begin{array}{c}\text { Volume }(\boldsymbol{\mu l}) \\
(8 \text { tubes })\end{array}$ \\
\hline Sigma water & - & 14.4 & 115.2 \\
\hline $5 \mathrm{X}$ buffer & $1 \mathrm{X}$ & 5 & 40 \\
\hline $25 \mathrm{mM} \mathrm{MgCl} 2$ & $1.5 \mathrm{mM}$ & 1.5 & 12 \\
\hline $10 \mathrm{mM} \mathrm{dNTP}$ & $0.2 \mathrm{mM}$ & 1 & 8 \\
\hline $\begin{array}{l}10 \mu \mathrm{M} \text { ISSR } \\
\text { Primer }\end{array}$ & $0.4 \mu \mathrm{M}$ & 1 & 8 \\
\hline Template DNA & $50-100 \mathrm{ng} / \mu \mathrm{l}$ & 2 & 16 \\
\hline $\begin{array}{l}\text { Taq DNA } \\
\text { Polymerase }\end{array}$ & $0.1 \mathrm{unit} / \mu \mathrm{l}$ & 0.1 & 0.8 \\
\hline \begin{tabular}{l} 
Total Volume: \\
\hline
\end{tabular} & $25 \mu \mathrm{l}$ & $200 \mathrm{ul}$ & \\
\hline
\end{tabular}

DNA template concentrations $(0,1,2,3,4$ and $5 \mu \mathrm{l})$ were optimum, all concentrations between (1-5 $\mu \mathrm{l})$ reproduced the amplification of PCR products but the clarity of bands decreased with the $2 \mu$ l template DNA (Figure $2 ; \mathrm{E}$ ). Optimum $\mathrm{MgCl}_{2}$ used at different concentrations $(0,1,1.5,2$, 2.5 and $3 \mu \mathrm{l}$ ) presented at $1.5 \mu \mathrm{MgCl}_{2}$ per PCR Master Mix where amplification showed clear amplification of PCR products that was reproducible and produced clear bands (Figure 2; F).

The optimization of PCR reagents at several treatments used ISSR primer (IS32). The optimum volumes for PCR reactions chosen were $5 \mathrm{X}$ PCR buffer $(5.0 \mu \mathrm{l}), 25 \mathrm{mM}$ $\mathrm{MgCl}_{2}(1.5 \mu \mathrm{l}), 10 \mathrm{mM}$ dNTP $(1 \mu \mathrm{l})$, ISSR primer $(1 \mu \mathrm{l})$, Template DNA $(2 \mu \mathrm{l})$ and 5 units/ml Taq polymerase $(0.1$ $\mu \mathrm{l})$. These conditions resulted in a sharp band and that was clearer when it was tested for all Oryza sativa L. regarding the amplification (Figure 2).

PCR buffer: selected to provide a monovalent salt environment and optimal $\mathrm{pH}$ for the final reaction volume. PCR buffer was necessary for optimizing Taq DNA activity and $5 \mu \mathrm{l}$ PCR buffers elicited clear amplification of PCR products bands. $1.5 \mu \mathrm{l} \mathrm{MgCl}$ per PCR master mix generated clear amplification of PCR products that were reproducible and produced clear bands. The lower concentration of $\mathrm{MgCl}_{2}$ increased the non-specificity and yield of the PCR product [15]. dNTP: clear bands and superb PCR results were observed in $1 \mu \mathrm{l}$. Many DNA isolation procedures also yielded large amounts of RNA - large amounts of RNA in the sample can chelate $\mathrm{Mg}$ and reduce the yielded DNA isolated. Kumari et al. [16] observed that high concentrations of $\mathrm{dNTP}$ reducesd free $\mathrm{Mg}$, interfering with the enzyme. ISSR primer: the concentration of $1 \mu$ of ISSR primer showed band clarity of PCR amplicons, while higher and lower concentrations of ISSR primer resulted in primer dimer formation and the absence of amplification. Kumari et al. [16] observed that high concentrations of ISSR primer may raise the probability of generating a templateindependent artifact, termed a primer-dimer, and could promote mispriming and accumulation of non-specific product. DNA template: the clarity of bands decreased with $2 \mu$ of template DNA, and there was the presence of smearing at higher concentrations of the DNA template, which affected the repeatability; there was an absence of amplification with lower concentration [15]. However, the Taq polymerase employed exhibited clear bands with $0.1 \mu \mathrm{l}$ Taq polymerase. Kumari et al. [16] found that high concentrations of Taq polymerase decreased specificity. Here, Taq polymerase remained active over a broad range of temperatures, and primer extension took place at low temperatures, including the annealing step. GC-rich templates were thought to be potentially problematic because of an inefficient separation of the two DNA strands or the tendency for the complementary GC-rich primers to form intermolecular secondary structures, which will compete with primers annealing to the template [17].
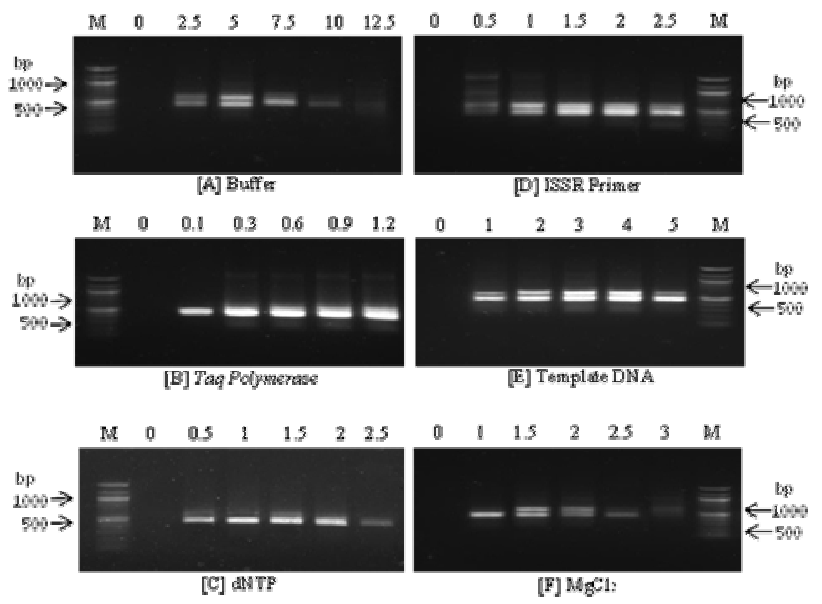

Fig. 2. PCR parameters optimization. Different volumes $(\mu \mathrm{l})$ of reagent (1.5\% agarose).

*M; DNA Marker 100 bp DNA ladder

[A]; Buffer concentrations $(0,2.5,5,7.5,10$, and $12.5 \mu \mathrm{l})$

[B]; Taq Polymerase concentrations $(0,0.1,0.3,0.6,0.9$ and $1.2 \mu \mathrm{l})$

[C]; dNTP concentrations $(0,0.5,1,1.5,2$, and $2.5 \mu \mathrm{l})$

[D]; ISSR Primer concentrations $(0,0.5,1,1.5,2$, and $2.5 \mu \mathrm{l})$

[E]; Template DNA concentrations $(0,1,2,3,4$ and $5 \mu \mathrm{l})$

$[\mathrm{F}] ; \mathrm{MgCl}_{2}$ concentrations $(0,1,1.5,2,2.5$ and $3 \mu \mathrm{l})$

In the present investigation, 100 ISSR primers, 20 degenerate commercial and 80 specific primers Table (6) were screened for amplification of rice for the optimum ISSR annealing temperature. However, for optimizing of primers used DNA one variety MRQ74 rice. The chosen optimizing annealing temperatures for PCR protocol was determined based on the great clear bands created. Seventeen degenerate and 39 specific ISSR primers were able to enhance amplified products at specific annealing temperature and were utilized for genotypical characteristics of rice examples. 
The optimal annealing temperature on choose primers are recorded in (Table 6). Result showed that both specific and degenerate primers gave positive amplification temperatures. The specific primers were given highest chance in the annealing process compared to degenerate primers and so were additionally beneficial in generating more polymorphisms to identify variations. Selected the clear and well visible bands were considered for better assessment. Consequently, 56 primers generated strong amplification products that were used for genetic analysis for annealing temperature for ISSR primers (Table 5).

The DNA isolation procedure for seedling was effectively utilised with application of certain modifications for DNA isolation; using fresh indica seedling was established as reliable for molecular characterization.

Optimum components and primer choices led to six annealing temperature to choose from $\left(60-45^{\circ} \mathrm{C}\right)$. On the other hand, 56 out of 100 ISSR primers (Table 4) were possible for use in the rice examination. The most suitable primers and amplified bands were utilised for Oryza sativa L. Saiki [18], which showed optimal primer annealing temperatures for a particular PCR amplification dependent on the concentration, length, nucleotide sequence and base composition of the primers. The higher temperature amplification of large fragments was favored whilst lower temperatures favored short fragment amplification [19].

The primer extension time relied upon the concentration and length of the target sequence as well as the extension temperature [20]. The adjustment of the annealing temperature allowed identifying a higher number of polymorphic loci for every combination [20]. Moraga-Suazo et al. [19] observed primer annealing temperatures and DNA concentration were critical factors for obtaining high banding-pattern quality.

TABLE IV

OPTIMUM ANNEALING TEMPERATURE FOR ISSR PRIMERS

\begin{tabular}{|c|c|c|c|}
\hline No. & $\begin{array}{c}\text { Annealing } \\
\text { Temperature }\left({ }^{\circ} \mathbf{C}\right)\end{array}$ & Total Primers & ISSR Primers \\
\hline $\mathbf{1}$ & 60 & 1 & IS 7 \\
\hline $\mathbf{2}$ & 58.8 & 3 & IS 20, IS 21, IS 60, IS 92 \\
\hline $\mathbf{3}$ & 56.9 & 9 & IS 29, IS 30, IS 43, IS 48, IS 69, IS 72, IS 89, IS 93, IS 94 \\
\hline $\mathbf{4}$ & 54.2 & 13 & IS 4, IS 10, IS 15, IS 27, IS 28, IS 31, IS 32, IS 33, IS 37, IS 40, IS 46, IS 51, IS 52 \\
\hline $\mathbf{5}$ & 50.7 & 10 & IS 19, IS 23, IS 24, IS 26, IS 44, IS 45, IS 49, IS 58, IS 83, IS 96 \\
\hline $\mathbf{6}$ & 47.8 & 20 & IS 1, IS 8, IS 11, IS 14, IS 16, IS 18, IS 22, IS 25, IS 35, IS 36, IS 38, IS 39, IS 42, \\
& & & IS 59, IS 85, IS 88, IS 90, IS 91, IS 95, \\
\hline
\end{tabular}

\section{CONCLUSIONS}

The conditions described in the present work suggest there was an ability to employ ISSR primers as an efficient determination tool for further molecular studies in particular rice species genetically, and has been documented for all rice varieties. The present optimized protocol for DNA isolation and ISSR technique may serve as a strong starting point for future genetic improvement and molecular characterization works in this promising rice plant.

\section{ACKNOWLEDGMENT}

This work was supported by Ministry of Higher Education and Scientific Research, Al-Muthanna University, Iraq; Malaysian Nuclear Agency Malaysia; and Universiti Kebangsaan Malaysia .

Corresponding author: arshad@mu.edu.iq; cradziah@ukm.edu.my; $\quad$ kkkihsan@yahoo.com; azhar_m@nuclearmalaysia.gov.my

\section{REFERENCES}

[1] C.C. Teoh, M. Mohd Nadzim, M.J. Mohd Shahmihaizan, I. Mohd Khairil Izani, K. Faizal, and H.B. Mohd Shukry . "Rice yield estimation using below cloud remote sensing images acquired by unmanned airborne vehicle system". International Journal on Advanced Science, Engineering and Information Technology, vol. 6, pp. 516-519. 2016.

[2] G.S. Khush, "What it will take to feed 5.0 billion rice consumers in 2030". Plant Mol. Biol. vol. 59, pp. 1-6. 2005.
[3] A. Satyanarayana, System of Rice Intensification-an innovative method to produce more with less water and inputs. In: Paper Presented in Fourth IWMI-Tata Annual Partners' Meet, IRMA, Anand, India, February, pp. 24-26. 2005.

[4] A.R.Nicolas and A.S. Cabarogias "Indigenous knowledge and sustainable pest management in rice farming communities of southeastern Luzon, Philippines" International Journal on Advanced Science, Engineering and Information Technology, vol. 5, pp. 440444. 2015.

[5] S.S. Kshirsagar, K.C. Samal, M. Rabha, D.N. Bastia, and G.R. Rout "Identification of variety diagnostic molecular marker of high yielding rice varieties" Proc. Natl. Acad. Sci., India, Sect. B Biol. Sci. vol.84, pp. 389-396. 2014.

[6] A.N. Alhasnawi, A.A. Kadhimi, A. Isahak, M.F. Ashraf, F. Doni, A. Mohamad, W.M. Wan Yusoff and C.C. Zain "Application of inter simple sequence repeat (ISSR) for detecting genetic analysis in rice (Oryza sativa L.) " Journal of Pure and Applied Microbiology. vol. 2, pp. 1091-1101. 2015.

[7] M.P. Reddy, N. Sarla and E.A. Siddiq "Inter simple sequence repeat (ISSR) polymorphism and its application in plant breeding" Euphytica. vol. 128, pp. 9-17. 2002.

[8] M.W. Blair, O. Panaud and S.R. McCouch "Inter-simple sequence repeat (ISSR) amplification for analysis of microsatellite motif frequency and fingerprinting in rice (Oryza sativa L.)" Theor Appl Genet. vol. 98, pp. 780-792. 1999.

[9] S.P. Joshi, V.S. Gupta, R.K. Aggarwal, P.K. Ranjekar and D.S. Brar "Genetic diversity and phylogenetic relationship as revealed by intersimple sequence repeat (ISSR) polymorphism in the genus Oryza. Theor" Appl. Genet. vol. 100, pp. 1311-1320. 2000.

[10] A.N. Alhasnawi "In vitro induction of local rice varieties, MRQ74 \& MR269 plant salt tolerance and assessment of variability through biochemical \& molecular marker" Genetic, P.hD. thesis, Faculty of Science and Technology, Universiti Kebangsaan Malaysia, Malaysia, July 2017.

[11] O.S.J. Pereira and P. Baptista "Optimization of DNA extraction for RAPD and ISSR analysis of Arbutus unedo L. leaves" Int. J. Mol. Sci. vol 12, pp. 4156-4164. 2011. 
[12] H. Grunenwald "Optimization of polymerase chain reactions" Methods in Molecular Biology. PCR Protocols, Eds.: J. M. S. Bartlett and D. Stirling (C) Humana Press Inc., Totowa, NJ, vol. 226, pp. 8999.2003.

[13] Z.A. Kadira, F. Daud, A. Mohamad, S. Senafi and R. Abdul Rashid "Optimization of primers derived from $\beta$-Glucan synthase gene consensus for molecular DNA fingerprinting in Pleurotus pulmonarious" The 15th. Postgraduate Colloquium, Fac. of Sc. \& Tech. 15-16 Apr 2015.

[14] J. Ferdous, M.M. Hanafi, M.Y. Rafii, and K. Muhammad "A quick DNA extraction protocol: Without liquid nitrogen in ambient temperature" African Journal of Biotechnology vol. 11, pp. 69566964. 2012.

[15] K. Padmalatha and M.V. Prasad "Optimization of DNA isolation and PCR protocol for RAPD analysis of selected medicinal and aromatic plants of conservation concern from Peninsular India" African Journal of Biotechnology vol. 5, pp. 230-234. 2005.

[16] P. Kumari, R.T. Manjunatha, A. Sane and M.N. Adarsh "Optimization of PCR Parameters for Molecular Characterization of Gladiolus Genotypes Using ISSR Markers” Indian J. of App. Res. vol. 5 pp. $685-687$.
[17] D.K. Lavanya, A. Sane, M.B. Shivanna and S. Ganeshan "Optimization of DNA isolation and PCR protocol for ISSR analysis of species of spilanthes - A medicinal herb from peninsular India" Intern. J. of Sci. and Res. vol. 3, pp. 1088-1091. 2014.

[18] R. K. Saiki "The design and optimization of the PCR, in PCR Technology". In Erlich, H.A. (ed.). Stockton Press. pp. 7-16. New York.1989.

[19] P. Moraga-Suazo, R. Hasbún, C. Balocchi and S. Valenzuela "Establishment and optimization of ISSR and SAMPL molecular markers as a tool for breeding programs of Pinus radiata" BOSQUE vol.1, pp. 93-98. 2012.

[20] J.M.S. Bartlett and D. Stirling "PCR protocols, second edition". In Park, D.J. (ed.) Methods in Molecular Biology. Vol. 226, pp 89-99. Humana Press Inc., Totowa, NJ. 2003.

[21] P. Costa, D. Pot, C. Dubos, J. Frigerio, C. Pionneau, C. Bodenes, E. Bertocchi, M. Cervera, D. Remington and C. Plomion "A genetic map of Maritime pine based on AFLP, RAPD and protein markers" Theoretical and Applied Genetics vol. 100, pp. 39-48. 2000. 
APPENDIX

TABLE V

POLYMORPHIC PRIMERS SHOW PRIMER SEQUENCE $\left(5^{\prime}-3^{\prime}\right)$ LENGTH, ANNEALING TEMPERATURE, AND PERCENTAGE OF AMPLIFIED BANDS $\mathrm{G}, \mathrm{A}, \mathrm{T}, \mathrm{C}$ AND $\mathrm{C}+\mathrm{G}$ CONTENT FOR ISSR PRIMERS

\begin{tabular}{|c|c|c|c|c|c|c|c|c|c|}
\hline \multirow{2}{*}{ No. } & \multirow{2}{*}{$\begin{array}{c}\text { Primer } \\
\text { name }\end{array}$} & \multirow{2}{*}{$\begin{array}{c}\text { Primer sequence } \\
\left(5^{\prime}-3^{\prime}\right)\end{array}$} & \multirow{2}{*}{$\begin{array}{l}\text { Length } \\
\text { (mers) }\end{array}$} & \multirow{2}{*}{$\begin{array}{l}\mathbf{T m} \\
\left({ }^{\circ} \mathbf{C}\right)\end{array}$} & \multicolumn{5}{|c|}{ Percentage of } \\
\hline & & & & & G & $\mathbf{A}$ & $\mathbf{T}$ & $\mathbf{C}$ & $\mathbf{C}+\mathbf{G}$ \\
\hline 1 & IS 1 & $(\mathrm{CAC})_{7} \mathrm{~T}$ & 22 & 47.8 & 0.0 & 31.8 & 4.5 & 63.6 & 63.6 \\
\hline 2 & IS 4 & $(\mathrm{CAC})_{7} \mathrm{G}$ & 22 & 54.2 & 4.5 & 31.8 & 0.0 & 63.6 & 68.1 \\
\hline 3 & IS 7 & $(\mathrm{CA})_{10} \mathrm{G}$ & 21 & 60 & 4.8 & 47.6 & 0.0 & 47.6 & 52.4 \\
\hline 4 & IS 8 & $(\mathrm{CT})_{9} \mathrm{G}$ & 19 & 47.8 & 5.3 & 0.0 & 47.4 & 47.4 & 52.7 \\
\hline 5 & IS 10 & $\operatorname{BDBT}(\mathrm{CCT})_{6}$ & 22 & 54.2 & 16.7 & 5.6 & 55.6 & 77.8 & 68.2 \\
\hline 6 & IS 11 & $\mathrm{HVH}(\mathrm{TCC})_{6}$ & 21 & 47.8 & 5.0 & 15.0 & 40.0 & 75.0 & 71.4 \\
\hline 7 & IS 14 & $(\mathrm{GA})_{8} \mathrm{~T}$ & 17 & 47.8 & 47.1 & 47.1 & 0.5 & 0.0 & 47.1 \\
\hline 8 & IS 15 & $(\mathrm{GA})_{8} \mathrm{C}$ & 17 & 54.2 & 47.1 & 47.1 & 0.0 & 5.9 & 53.0 \\
\hline 9 & IS 16 & $(\mathrm{GA})_{8} \mathrm{~A}$ & 17 & 47.8 & 47.1 & 52.9 & 0.0 & 0.0 & 47.1 \\
\hline 10 & IS 18 & $(\mathrm{CT})_{8} \mathrm{G}$ & 17 & 47.8 & 5.9 & 0.0 & 47.1 & 47.1 & 53.0 \\
\hline 11 & IS 19 & $(\mathrm{CT})_{8} \mathrm{~T}$ & 17 & 50.7 & 0.0 & 0.0 & 52.9 & 47.1 & 47.1 \\
\hline 12 & IS 20 & $(\mathrm{CA})_{8} \mathrm{~A}$ & 17 & 58.8 & 0.0 & 52.9 & 0.0 & 47.1 & 47.1 \\
\hline 13 & IS 21 & $(\mathrm{CA})_{8} \mathrm{G}$ & 17 & 58.8 & 5.9 & 47.1 & 0.0 & 47.1 & 53.0 \\
\hline 14 & IS 22 & $(\mathrm{GT})_{8} \mathrm{~A}$ & 17 & 47.8 & 47.1 & 5.9 & 47.1 & 0.0 & 47.1 \\
\hline 15 & IS 23 & $(\mathrm{GT})_{8} \mathrm{C}$ & 17 & 50.7 & 47.1 & 0.0 & 47.1 & 5.9 & 53.0 \\
\hline 16 & IS 24 & $(\mathrm{GT})_{8} \mathrm{~T}$ & 17 & 50.7 & 47.1 & 0.0 & 52.9 & 0.0 & 47.1 \\
\hline 17 & IS 25 & $(\mathrm{TC})_{8} \mathrm{~A}$ & 17 & 47.8 & 0.0 & 5.9 & 47.1 & 47.1 & 47.1 \\
\hline 18 & IS 26 & $(\mathrm{GT})_{9} \mathrm{C}$ & 19 & 50.7 & 47.1 & 0.0 & 47.1 & 5.3 & 52.4 \\
\hline 19 & IS 27 & $(\mathrm{GT})_{7} \mathrm{GGTG}$ & 18 & 54.2 & 58.8 & 0.0 & 47.1 & 0.0 & 58.8 \\
\hline 20 & IS 28 & $(\mathrm{AC})_{8} \mathrm{~T}$ & 17 & 54.2 & 0.0 & 47.1 & 5.9 & 47.1 & 47.1 \\
\hline 21 & IS 29 & $(\mathrm{AC})_{8} \mathrm{C}$ & 17 & 56.9 & 0.0 & 47.1 & 0.0 & 52.9 & 52.9 \\
\hline 22 & IS 30 & $(\mathrm{AC})_{8} \mathrm{G}$ & 17 & 56.9 & 5.9 & 47.1 & 0.0 & 47.1 & 47.1 \\
\hline 23 & IS 31 & $(\mathrm{TG})_{8} \mathrm{~A}$ & 17 & 54.2 & 47.1 & 5.9 & 47.1 & 0.0 & 47.1 \\
\hline 24 & IS 32 & $(\mathrm{TG})_{8} \mathrm{G}$ & 17 & 54.2 & 52.9 & 0.0 & 47.1 & 0.0 & 52.9 \\
\hline 25 & IS 33 & $(\mathrm{AG})_{8} \mathrm{YT}$ & 18 & 54.2 & 44.4 & 44.4 & 11.1 & 5.6 & 50.0 \\
\hline 26 & IS 35 & $(\mathrm{CT})_{8} \mathrm{RA}$ & 18 & 47.8 & 5.6 & 11.1 & 44.4 & 44.4 & 50.0 \\
\hline 27 & IS 36 & $(\mathrm{CT})_{8} \mathrm{RC}$ & 18 & 47.8 & 5.6 & 5.6 & 44.4 & 50.0 & 55.6 \\
\hline 28 & IS 37 & $(\mathrm{CA})_{8} \mathrm{RT}$ & 18 & 54.2 & 5.6 & 50.0 & 5.6 & 44.4 & 50.0 \\
\hline 29 & IS 38 & $(\mathrm{CA})_{8} \mathrm{RC}$ & 18 & 47.8 & 5.6 & 50.0 & 0.0 & 50.0 & 50.0 \\
\hline 30 & IS 39 & $(\mathrm{GT})_{8} \mathrm{YA}$ & 18 & 47.8 & 44.4 & 5.6 & 50.0 & 5.6 & 50.0 \\
\hline 31 & IS 40 & $(\mathrm{GT})_{8} \mathrm{YG}$ & 18 & 54.2 & 50.0 & 0.0 & 50.0 & 5.6 & 55.6 \\
\hline 32 & IS 42 & $(\mathrm{AC})_{8} \mathrm{YG}$ & 18 & 47.8 & 5.6 & 44.4 & 5.6 & 50.0 & 55.6 \\
\hline 33 & IS 43 & $(\mathrm{AC})_{8} \mathrm{YA}$ & 18 & 56.9 & 0.0 & 50 & 5.6 & 50.0 & 50.0 \\
\hline 34 & IS 44 & $(\mathrm{AC})_{8} \mathrm{YT}$ & 18 & 50.7 & 0.0 & 44.4 & 11.1 & 50.0 & 50.0 \\
\hline 35 & IS 45 & $(\mathrm{TG})_{8} \mathrm{RT}$ & 18 & 50.7 & 50.0 & 50.6 & 50.0 & 0.0 & 50.0 \\
\hline 36 & IS 46 & $(\mathrm{TG})_{8} \mathrm{RC}$ & 18 & 54.2 & 50.0 & 5.6 & 44.4 & 5.6 & 55.6 \\
\hline 37 & IS 48 & $(\mathrm{ATG})_{8}$ & 24 & 56.9 & 33.3 & 33.3 & 33.3 & 0.0 & 33.0 \\
\hline 38 & IS 49 & $(\mathrm{CTC})_{6}$ & 18 & 50.7 & 0.0 & 0.0 & 33.3 & 66.7 & 66.7 \\
\hline 39 & IS 51 & $(\mathrm{GACA})_{6}$ & 24 & 54.2 & 25.0 & 50.0 & 0.0 & 25 & 50.0 \\
\hline 40 & IS 52 & $(\mathrm{TCC})_{5} \mathrm{RY}$ & 17 & 54.2 & 5.9 & 5.9 & 35.3 & 64.7 & 55.6 \\
\hline 41 & IS 58 & $(\mathrm{GT})_{8} \mathrm{YC}$ & 18 & 50.7 & 44.4 & 0.0 & 50 & 11.1 & 55.6 \\
\hline 42 & IS 59 & $(\mathrm{GGAGA})_{3}$ & 15 & 47.8 & 60.0 & 40.0 & 0.0 & 0.0 & 60.0 \\
\hline 43 & IS 60 & $\mathrm{BDB}(\mathrm{CA})_{7}$ & 17 & 58.8 & 17.6 & 47.1 & 17.6 & 52.9 & 58.8 \\
\hline 44 & IS 69 & $(\mathrm{TGG})_{5}$ & 15 & 56.9 & 66.7 & 0.0 & 33.3 & 0.0 & 66.7 \\
\hline 45 & IS 72 & $(\mathrm{GTC})_{5}$ & 15 & 56.9 & 33.3 & 0.0 & 33.3 & 33.3 & 66.6 \\
\hline 46 & IS 83 & $(\mathrm{AG})_{5} \mathrm{TTG}$ & 13 & 50.7 & 46.2 & 38.5 & 15.4 & 0.0 & 46.2 \\
\hline 47 & IS 85 & $(\mathrm{CT})_{5} \mathrm{CACC}$ & 14 & 47.8 & 57.1 & 7.1 & 35.7 & 0.0 & 57.1 \\
\hline 48 & IS 88 & $(\mathrm{AG})_{8} \mathrm{~T}$ & 17 & 47.8 & 47.1 & 47.1 & 5.9 & 0.0 & 47.1 \\
\hline 49 & IS 89 & $(\mathrm{AG})_{8} \mathrm{C}$ & 17 & 56.9 & 47.1 & 47.1 & 0.0 & 5.9 & 53.0 \\
\hline 50 & IS 90 & $(\mathrm{AG})_{8} \mathrm{G}$ & 17 & 47.8 & 52.9 & 47.1 & 0.0 & 0.0 & 52.9 \\
\hline 51 & IS 91 & $(\mathrm{CA})_{8} \mathrm{~T}$ & 17 & 47.8 & 0.0 & 47.1 & 5.9 & 47.1 & 47.1 \\
\hline 52 & IS 92 & $(\mathrm{CA})_{8} \mathrm{C}$ & 17 & 58.8 & 0.0 & 47.1 & 0.0 & 52.9 & 52.9 \\
\hline 53 & IS 93 & $(\mathrm{AGC})_{6}$ & 18 & 56.9 & 33.3 & 33.3 & 0.0 & 33.3 & 66.6 \\
\hline 54 & IS 94 & $(\mathrm{ATG})_{6}$ & 18 & 56.9 & 33.3 & 33.3 & 33.3 & 0.0 & 33.3 \\
\hline 55 & IS 95 & $(\mathrm{GATA})_{4}$ & 16 & 47.8 & 25.0 & 50.0 & 25.0 & 0.0 & 25.0 \\
\hline 56 & IS 96 & $(\mathrm{GACA})_{4}$ & 16 & 50.7 & 25.0 & 50.0 & 0.0 & 25 & 50.0 \\
\hline Total & & & 995 & & 1462.5 & 1523.6 & 1316 & 1553.8 & 2943 \\
\hline
\end{tabular}

$\mathrm{B}=\mathrm{C}, \mathrm{G}, \mathrm{T} ; \mathrm{D}=\mathrm{A}, \mathrm{G}, \mathrm{T} ; \mathrm{H}=\mathrm{A}, \mathrm{C}, \mathrm{T} ; \mathrm{R}=\mathrm{A}, \mathrm{G} ; \mathrm{V}=\mathrm{A}, \mathrm{C}, \mathrm{G} ; \mathrm{Y}=\mathrm{C}, \mathrm{T}$ 
TABLE VI

SUMMARY INFORMATION FOR EACH 100 ISSR PRIMERS AFTER PCR OPTIMIZATION

* THE BOX INDICATE A SIGNIFICANT AMPLIFICATION PRODUCTS A GOOD BANDS

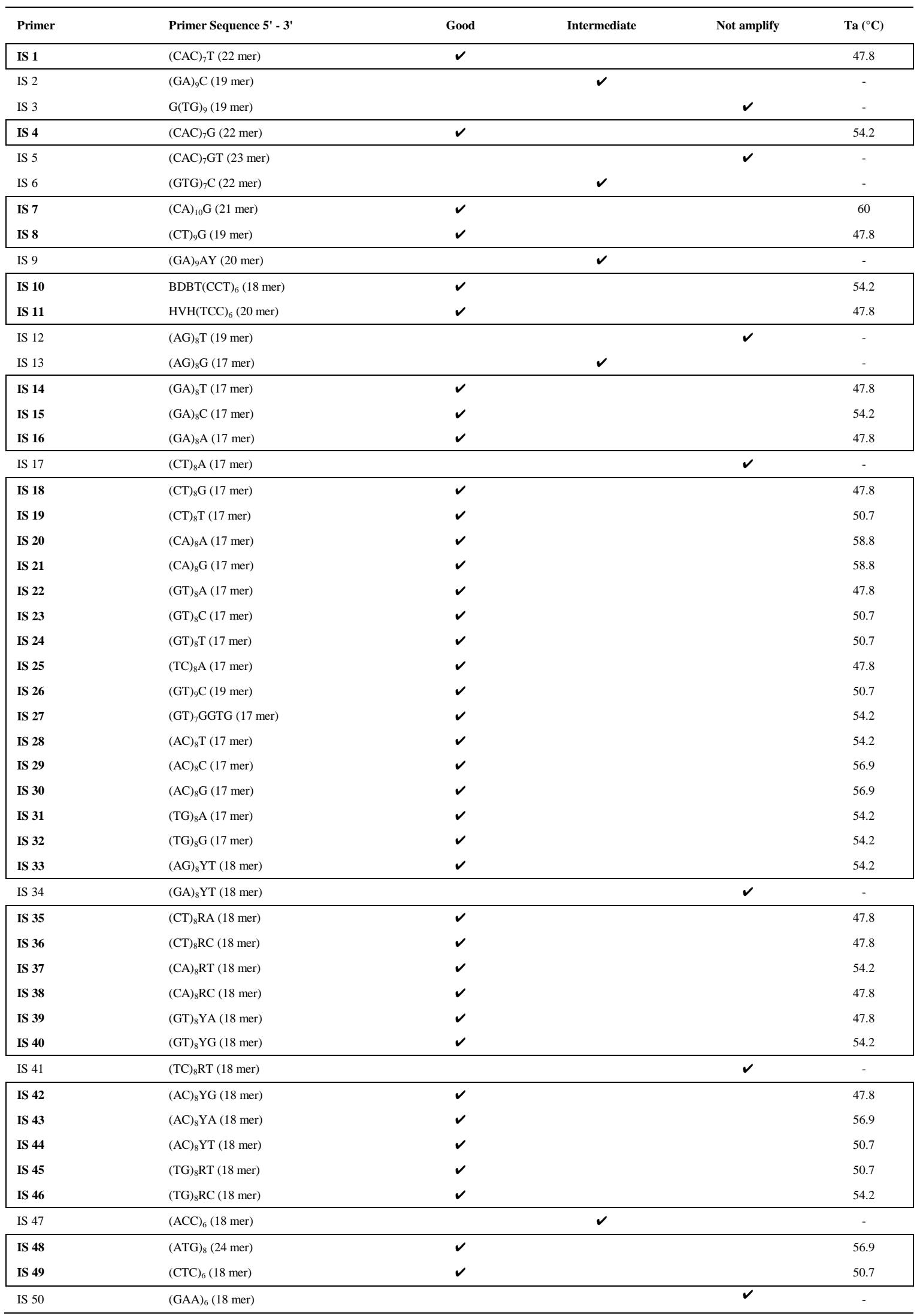

to be continued... 
... continuation

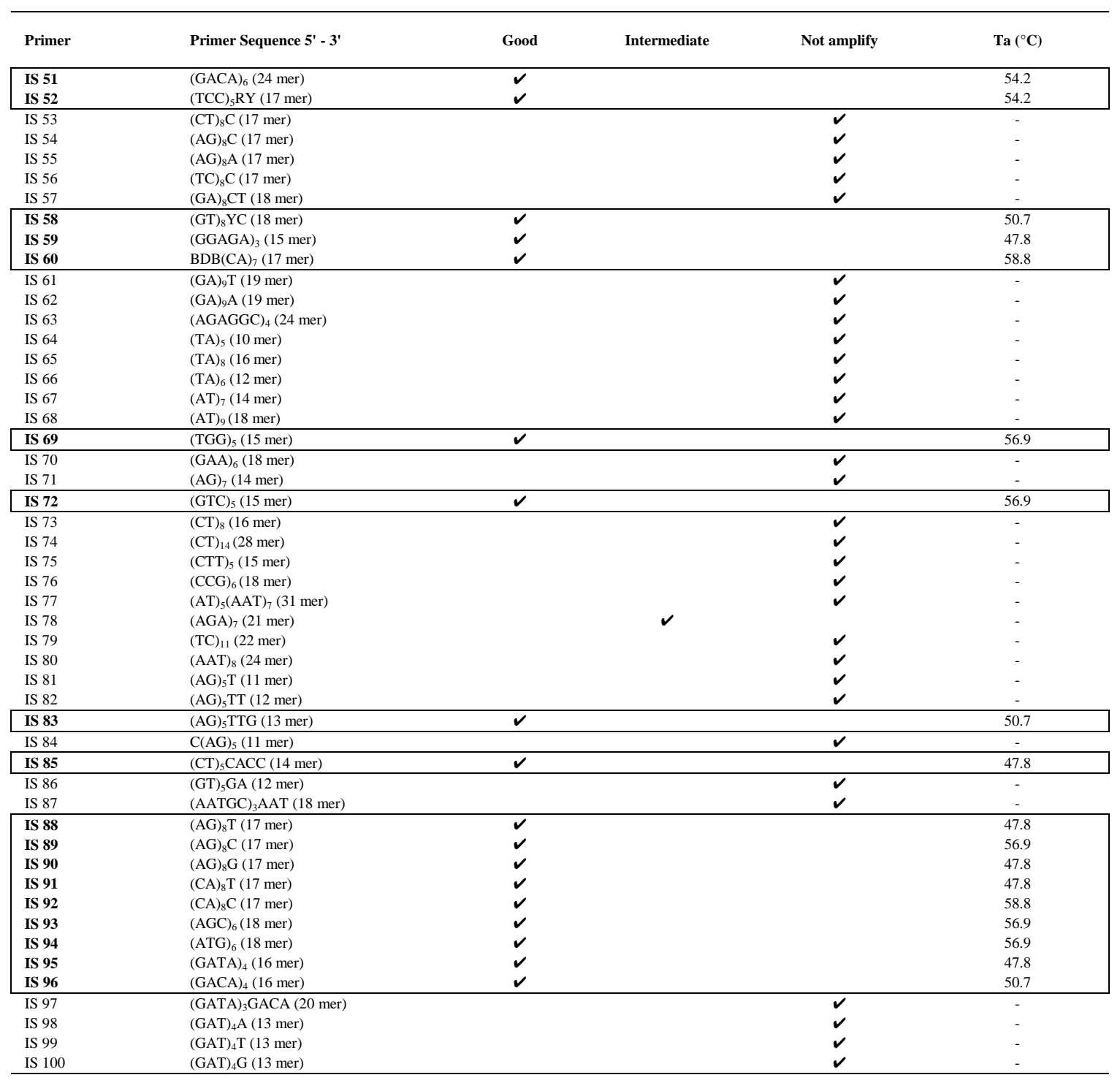

$\mathrm{B}=\mathrm{C}, \mathrm{G}, \mathrm{T} ; \mathrm{D}=\mathrm{A}, \mathrm{G}, \mathrm{T} ; \mathrm{H}=\mathrm{A}, \mathrm{C}, \mathrm{T} ; \mathrm{R}=\mathrm{A}, \mathrm{G} ; \mathrm{V}=\mathrm{A}, \mathrm{C}, \mathrm{G} ; \mathrm{Y}=\mathrm{C}, \mathrm{T}$ 